\title{
Antioxidant, Glucose Uptake Stimulatory, $\alpha$-Glucosidase and $\alpha$-Amylase Inhibitory Effects of Myrianthus arboreus Stem Bark
}

Harley $\mathrm{BK}^{1^{*}}$, Dickson $\mathrm{RA}^{1}$ and Fleischer $\mathrm{TC}^{2}$

${ }^{1}$ Department of Pharmacognosy, Faculty of Pharmacy and Pharmaceutical Sciences, College of Health Sciences, KNUST, Kumasi, Ghana

${ }^{2}$ Department of Herbal Medicine, Faculty of Pharmacy and Pharmaceutical Sciences, College of Health Sciences, KNUST, Kumasi, Ghana

*Corresponding author: Harley BK, Faculty of Pharmacy and Pharmaceutical Sciences, College of Health Sciences, Department of Pharmacognosy, Kwame Nkrumah University of Science and Technology, Kumasi Ashanti Region, Ghana, Tel: +2330265398208; E-mail: bnjmnharley@yahoo.com

Received: May 16, 2017; Accepted: May 25, 2017; Published: May 30, 2017

Copyright: (C) 2017 Harley BK, et al. This is an open-access article distributed under the terms of the Creative Commons Attribution License, which permits unrestricted use, distribution, and reproduction in any medium, provided the original author and source are credited.

\begin{abstract}
Myrianthus arboreus is used traditionally in the management of diabetes in Ghana. The study seeks to evaluate the antioxidant, glucose uptake, $\alpha$-glucosidase and $\alpha$-amylase inhibitory activities of the stem bark to support its folkloric use. The ethanol stem bark extract of $M$. arboreus was partitioned successively with petroleum ether, chloroform, ethyl acetate and n-butanol. The extract and fractions were evaluated for their glucose uptake effects in C2C12 myotubes and 3T3-L1 adipocytes. Their inhibitory action on $\alpha$-glucosidase and a-amylase were also investigated whereas their antioxidant activities were evaluated using the DPPH and nitric oxide scavenging assays. The crude extract was further evaluated for its phenolic content, antioxidant capacity and reducing power. The stem bark extract significantly $(\mathrm{P}<0.05)$ stimulated glucose uptake in $\mathrm{C} 2 \mathrm{C} 12$ myotubes and 3T3-L1 adipocytes when compared to control and also showed potent inhibitory activities against $\alpha$-glucosidase and $\alpha$-amylase with 11-fold and 5-fold better activity than acarbose respectively. The DPPH and nitric oxide radical scavenging effect of the extract were comparable with the ascorbic acid and a-tocopherol respectively. The extract had high phenol content with tannic acid equivalent of $(114.70 \pm 10.48) \mathrm{mg} / \mathrm{g}$ with an ascorbic acid equivalent of $(98.34 \pm 14.50) \mathrm{mg} / \mathrm{g}$. The fractions demonstrated varying glucose uptake and enzyme inhibitory activities with the ethyl acetate fraction being the most potent. The ethyl acetate fraction demonstrated the highest scavenging effect on the DPPH and nitric oxide radicals. $M$. arboreus stem bark extract showed significant antioxidant, glucose uptake and enzyme inhibitory activities justifying its use in traditional medicine.
\end{abstract}

Keywords: Myrianthus arboreus, Antioxidant; $\alpha$-Amylase inhibition; a-Glucosidase inhibition; Muscle cells; Adipocytes

\section{Introduction}

Diabetes mellitus is a metabolic disorder, of multiple aetiology, characterized by chronic hyperglycemia, with disturbances of carbohydrate, fat and protein metabolism. This is as a result of the defects in the secretion of insulin, action of insulin or both [1]. There are two types of diabetes mellitus; Type 1 diabetes mellitus and Type 2 diabetes mellitus. The disease affects about 382 million people worldwide and is expected to increase to 592 million people by 2035 , with majority of the people living in low- and middle-income countries [2]. The number of people with diabetes appears to be increasing in every country and this has been attributed to the rapid rise in unhealthy life style, urbanization and aging [3].

Type 2 diabetes mellitus is caused by insulin resistance which is defined as defective insulin signaling and a decreased insulin efficiency to induce the glucose transport from blood into peripheral tissues such as the muscles and fat cells [4]. This results in increased levels of blood glucose. Some of the currently available antidiabetic drugs improve blood glucose levels by increasing the glucose uptake in peripheral tissues. However, such drugs are associated with adverse side effects, which limit their use in diabetic patients. Therefore, it is highly desirable to discover antidiabetic agents that improve blood glucose levels with minimal side effects.
Postprandial hyperglycemia observed in type 2 diabetes mellitus could induce the nonenzymatic glycosylation of several proteins resulting in the development of chronic complications in diabetes [5]. Therefore, control of postprandial plasma glucose levels is critical in the treatment of diabetes and in preventing chronic vascular complications. One therapeutic approach for reducing postprandial hyperglycaemia is by retarding the absorption of glucose through the inhibition of carbohydrate metabolizing enzymes, $\alpha$-glucosidase and $a$-amylase, in the digestive tract. Inhibition of these enzymes retard the catabolism of dietary carbohydrates to D-glucose and delay the absorption of glucose into the blood stream thereby reducing postprandial hyperglycemia [6].

In diabetes mellitus, chronic hyperglycemia results in the increased production of reactive oxygen species leading to oxidative stress. A well-known mechanism involved in the pathogenesis of diabetic complications such as retinopathy, neuropathy and nephropathy [7]. Antioxidants have been shown to attenuate the diabetic-induced oxidative stress and lipid peroxidation observed in diabetic animals [8] thus medicinal plants with hypoglycemic effects containing natural antioxidants which can preserve $\beta$-cell function [9] and retard the formation of diabetes - induced reactive oxygen species (ROS) may provide potential alternative therapeutic approaches for managing the disease [10].

Myrianthus arboreus P. Beauv (Moraceae), commonly known as "Anyankoma" by the Akans in Ghana is a tree that grows in the West African rainforests [11]. The plant is used in traditional medicine with various parts employed in treatment of several diseases. The leaves are 
used in the treatment of dysentery, diarrhoea and vomiting [12]. Myrianthus arboreus leaves are used as analgesic in the treatment of muscular pains, fractures and hemorrhoids. Bark decoctions of the plant are used in the treatment of malaria; fever and diabetes. The roots are diced and prepared together with the seeds of Aframomum melegueta K.Schum as a vapour bath against headache [13].

In our previous study on Myrianthus arboreus, reported that the ethanol stem bark extract exhibited hypoglycemic and antihyperlipidemic activities in Streptozotocin-induced diabetic rats [14]. In this report, we present the glucose uptake stimulatory effect and the $\alpha$-amylase and $\alpha$-glucosidase inhibitory activities of the extract and fractions as some of the mechanisms by which the plant exerts its hypoglycemic action. The study also reports on the in vitro antioxidant activities of the ethanol stem bark extract and fractions.

\section{Materials and Methods}

\section{Chemicals and reagents}

Acarbose, rat intestinal acetone powder, porcine pancreatic $\alpha$ amylase, 2,2-diphenyl-1-picrylhydrazyl (DPPH), ferric chloride, FolinCiocalteu reagent, $p$-nitrophenyl- $\alpha$-D-glucopyranoside, dinitrosalicylic acid (DNS), potassium ferricyanide, Griess reaction reagent, accutase, cytochalasin B, 3-Isobutyl-1-methylxanthine (IBMX), 2-Deoxy-Dglucose were products of Sigma (St. Louis, MO, USA). in Dulbecco's modified Eagle's Medium (DMEM), fetal calf serum (FCS), newborn calf serum (NBCS), L-glutamine, horse serum and Penicillin/ Streptomycin were purchased from Gibco (Berlin, Germany). C2C12 myoblasts (CRL-1772) and 3T3-L1 pre-adipocytes (CL-173) were obtained from American Type Culture Collection (ATCC). $\left[{ }^{3} \mathrm{H}\right] 2$ 2DOG $\left(\left[{ }^{3} \mathrm{H}\right]\right.$ 2-deoxyglucose) and liquid scintillation cocktail, Ultima Gold XR, were obtained from Perkinelmer (Waltham, MA, USA). All solvents and chemicals used in the experiments were of analytical reagent grades.

\section{Plant material collection, extraction and fractionation}

The stem bark of $M$. arboreus was collected from Kwahu, in the Eastern Region of Ghana, in March 2013. The plant was identified and authenticated at the Department of Herbal Medicine, College of Health Sciences, Kwame Nkrumah University of Science, and Technology herbarium where voucher specimen (KNUST/HM 1/2013/S005) has been deposited. The stem barks were cut into pieces, dried in an oven at $40^{\circ} \mathrm{C}$ and coarsely powdered. $1.5 \mathrm{~kg}$ of the powder was Soxhlet extracted for $48 \mathrm{~h}$ using $70 \%$ ethanol and the liquid extract concentrated under reduced pressure at $40^{\circ} \mathrm{C}$ until the solvent for extraction was completely removed to obtain a brown residue (MAB). (Yield: $5.1 \% \mathrm{w} / \mathrm{w}$.). $70 \mathrm{~g}$ of the crude extract so obtained was solvent fractionated by partitioning the suspended extract in water with petroleum ether, chloroform, ethyl acetate and n-butanol successively to yield fractions: MAB1, MAB2, MAB3 and MAB4 respectively. The aqueous residue obtained was considered as fraction MAB5.

\section{Inhibition of $\alpha$-amylase}

The a-amylase inhibitory activity was determined by an assay modified from the Worthington Enzyme Manual [15]. A total of 500 $\mu \mathrm{L}$ of the experimental sample (MAB, fractions and acarbose) was added to $500 \mu \mathrm{L}$ of $0.02 \mathrm{M}$ phosphate buffer ( $\mathrm{pH}$ 6.9) containing $\alpha$ amylase $(0.5 \mathrm{mg} / \mathrm{mL})$ solution. The mixture was incubated at $25^{\circ} \mathrm{C}$ for $10 \mathrm{~min} .500 \mu \mathrm{L}$ of a $1 \%$ starch solution in $0.02 \mathrm{M}$ sodium phosphate buffer ( $\mathrm{pH}$ 6.9) was added to each tube. The reaction mixtures were then incubated at $25^{\circ} \mathrm{C}$ for $10 \mathrm{~min}$ after which the reaction was stopped by adding $1.0 \mathrm{~mL}$ of 3,5-dinitrosalicylic acid colour reagent ( $1 \% 3,5$ - dinitrosalicylic acid and $12 \%$ sodium potassium tartrate in 0.4 $\mathrm{M} \mathrm{NaOH}$ ). The test tubes were incubated in boiling water for $5 \mathrm{~min}$ and cooled to room temperature. Absorbance was measured at $540 \mathrm{~nm}$ after diluting the reaction mixture with $10 \mathrm{ml}$ of distilled water. The $\alpha$ amylase inhibitory activity was expressed as percentage inhibition and calculated as follows:

$$
\% \text { Inhibition }=\frac{A_{540}^{\text {Control }}-A_{540}^{\text {Extract }}}{A_{540}^{\text {Control }}} \times 100
$$

\section{Inhibition of $\alpha$-glucosidase}

A modified version of the assay described by Worthington Enzyme Manual [15] was followed. A volume of $50 \mu \mathrm{L}$ of sample (MAB and fractions) $(1-100 \mu \mathrm{g} / \mathrm{mL})$ and acarbose $(10-1000 \mu \mathrm{g} / \mathrm{mL})$ and $100 \mu \mathrm{L}$ of $0.1 \mathrm{M}$ phosphate buffer ( $\mathrm{pH}$ 6.9) containing crude $\alpha$-glucosidase solution $(25 \mathrm{mg} / \mathrm{mL})$ was incubated in 96 -well plates at $25^{\circ} \mathrm{C}$ for 10 minutes. $50 \mu \mathrm{L}$ of $5 \mathrm{mM} p$-nitrophenyl- $\alpha$-D-glucopyranoside solution in $0.1 \mathrm{M}$ phosphate buffer $(\mathrm{pH}$ 6.9) was then added to each well at timed intervals after incubation. The reaction mixture was then incubated for 30 minutes at $37^{\circ} \mathrm{C}$. Before and after incubation, the 4nitrophenol absorbance was measured at $405 \mathrm{~nm}$ using a micro-array reader (Thermomax, Molecular Device Corp., Sunnyvale, CA) and compared to a control that had $50 \mu \mathrm{L}$ of buffer solution in place of the extract. The a-glucosidase inhibitory activity was expressed as percentage inhibition and calculated as follows:

$$
\% \text { Inhibition }=\frac{\Delta A_{405}^{\text {Control }}-\Delta A_{405}^{\text {Extract }}}{\Delta A_{405}^{\text {Control }}} \times 100
$$

\section{Cell culture}

C2C12 myotubes: C2C12 myoblasts (CRL-1772) were cultured in Dulbecco's modified Eagle's Medium (DMEM; Gibco, Berlin, Germany) containing $10 \%$ fetal calf serum (FCS), $2 \mathrm{Mm}$ glutamine, $100 \mathrm{unit} / \mathrm{ml}$ penicillin, and $100 \mathrm{mg} / \mathrm{mLstreptomycin}$. The cells were cultured at $37^{\circ} \mathrm{C}$ in a humidified atmosphere containing $5 \% \mathrm{CO} 2$ pressure. When the cells had achieved $70 \%$ - 80\% confluence, differentiation of myoblasts into myotubes was induced by replacing the media with DMEM containing $2 \%$ horse serum, $2 \mathrm{mM}$ glutamine, $100 \mathrm{unit} / \mathrm{mL}$ penicillin, and $100 \mathrm{mg} / \mathrm{mL}$ streptomycin. Four days after fusion, the differentiated myotubes were used for the experiments.

3T3-L1 adipocytes: 3T3-L1 fibroblasts (CL-173) were cultured in DMEM supplemented with $10 \%$ newborn calf serum (NBCS) and $1 \%$ Penicillin/Streptomycin in $5 \% \mathrm{CO}_{2}$ at $37^{\circ} \mathrm{C}$. Differentiation was initiated by treating the cells with DMEM containing 3-Isobutyl-1methylxanthine (IBMX, $0.5 \mathrm{mM}$ ), $1 \mu \mathrm{M}$ dexamethasone, $1 \%$ Penicillin/ Streptomycin and 10\% FCS for 48 hours. The cells were re-fed with DMEM containing 10\% FCS, $1 \%$ Penicillin/Streptomycin and $10 \mu \mathrm{M}$ human Insulin for the next 48 hours after which cells were kept in maintenance media (DMEM+10\% FCS and 1\% Penicillin/ Streptomycin). More than $90 \%$ of the cells expressed adipocyte phenotype between 12 and 16 days after the initiation of differentiation and were used for the glucose uptake. 


\section{Glucose uptake assays}

Glucose uptake in $\mathrm{C} 2 \mathrm{C} 12$ myotubes: Glucose uptake was assayed by measuring the uptake of $\left[{ }^{3} \mathrm{H}\right] 2$-DOG $\left(\left[{ }^{3} \mathrm{H}\right]\right.$ 2-deoxyglucose) (Perkinelmer, NET549A) in 24-well plates [16]. Glucose uptake measurements were performed in three independent experiments. The experiments were carried out at room temperature and every well was processed individually. Briefly, after 5 days of differentiation, $\mathrm{C} 2 \mathrm{C} 12$ myotubes were serum starved for $4 \mathrm{~h}$ in DMEM containing $1 \%$ Penicillin/Streptomycin. Myotubes were then treated with MAB and fractions ( 10 and $30 \mu \mathrm{g} / \mathrm{mL}$ ) for $60 \mathrm{~min}$ and washed two times with 500 $\mu \mathrm{L}$ HBS-buffer [10 mM HEPES (pH 7.4), $140 \mathrm{mM} \mathrm{NaCl}, 5 \mathrm{mM} \mathrm{KCl}$, $2.5 \mathrm{mM} \mathrm{MgSO}_{4}$., and $1 \mathrm{mM} \mathrm{CaCl}_{2}$ ]. The HBS-buffer was aspirated and immediately replaced with $400 \mu \mathrm{L}$ of Glucose uptake-buffer (HBSbuffer containing $2 \mu \mathrm{Ci}\left[{ }^{3} \mathrm{H}\right] 2$-DOG/mL and $10 \mu \mathrm{M} 2$-DOG) and the cells incubated for $5 \mathrm{~min}$. The glucose-uptake buffer was then aspirated and the uptake of glucose terminated by the immediate addition of CB-stop solution (HBS-buffer containing $10 \mu \mathrm{M}$ Cytochalasin B). The cells were kept on ice for $15 \mathrm{~min}$ and then washed thrice with ice-cold PBS solution which was afterwards aspirated to the last drop. The cells were lysed in $400 \mu \mathrm{L}$ of $0.2 \mathrm{M} \mathrm{NaOH}$ overnight with slight agitation (60 $\mathrm{rpm})$, at $37^{\circ} \mathrm{C}$. This was done in a humid chamber to avoid evaporation. The dissolved cells were transferred into a $500 \mu \mathrm{L}$ deep well plate. $\left[{ }^{3} \mathrm{H}\right]$ 2-DOG levels were counted in $200 \mu \mathrm{L}$ cell lysate in 4 $\mathrm{mL}$ of Ultima Gold XR using a liquid scintillation analyzer (Packard TRI-CARB ${ }^{\circ}$ 2200CA). The BCA-protein content of dissolved cells were determined using the Pierce BCA-Protein Assay Kit and compared to a BSA Standard-curve prepared in $0.2 \mathrm{M} \mathrm{NaOH}$. The glucose uptake data was expressed in cpm/mg of protein. $10 \mathrm{nM}$ IGF-1 was used as a positive control. Non-specific glucose uptake was determined by adding $10 \mathrm{uM}$ of Cytochalasin $\mathrm{B}$ to $200 \mu \mathrm{L}$ of radioactive glucose uptake buffer. This solution was incubated and processed in parallel to the test samples for glucose uptake.

Glucose uptake in 3T3-L1 adipocytes: Glucose uptake was assayed by measuring the uptake of $\left[{ }^{3} \mathrm{H}\right] 2$-DOG $\left(\left[{ }^{3} \mathrm{H}\right] 2\right.$-deoxyglucose) in 24 well plates [17]. Glucose uptake measurements were performed in three independent experiments. The experiments were carried out at room temperature and every well was processed individually. 3T3-L1 adipocytes 15 days of post initiation were washed thrice with starvation medium (DMEM, high glucose containing 1\% Penicillin/ Streptomycin) and serum starved for $4 \mathrm{~h}$ at $37^{\circ} \mathrm{C}$ in a humidified atmosphere of $5 \% \mathrm{CO}_{2}$. The adipocytes were then treated with $\mathrm{MAB}$ and fractions ( 10 and $30 \mu \mathrm{g} / \mathrm{mL}$ ) for $60 \mathrm{~min}$ and washed with $400 \mu \mathrm{L}$ KRP-buffer [10 mM Na $2 \mathrm{HPO}_{4}$ (pH 7.4), $130 \mathrm{mM} \mathrm{NaCl}, 5 \mathrm{Mm} \mathrm{KCl}, 1.3$ $\mathrm{mM} \mathrm{MgSO}_{4}$, and $1.3 \mathrm{mM} \mathrm{CaCl}_{2}$ ]. $400 \mu \mathrm{L}$ of Glucose uptake-buffer (KRP-buffer containing $1 \mu \mathrm{Ci}\left[{ }^{3} \mathrm{H}\right] 2$-DOG/mL and $100 \mu \mathrm{M}$ 2-DOG) was added to each well after aspiration of the KRP-buffer and incubated for $10 \mathrm{~min}$. The glucose-uptake buffer was then aspirated and glucose uptake terminated immediately by the addition of CB-stop solution (KRP-buffer containing $10 \mu \mathrm{M}$ Cytochalasin B). The cells were kept on ice for $10 \mathrm{~min}$ and then washed thrice with ice-cold PBS solution which was afterwards aspirated to the last drop. The cells were lysed in $400 \mu \mathrm{L}$ of $0.2 \mathrm{M} \mathrm{NaOH}$ overnight with slight agitation (60 $\mathrm{rpm}$ ), at $37^{\circ} \mathrm{C}$. This was done in a humid chamber to avoid evaporation. The dissolved cells were transferred into a $500 \mu \mathrm{L}$ deep well plate. $200 \mu \mathrm{L}$ cell lysate of each well was well mixed with $4 \mathrm{~mL}$ of liquid scintillation cocktail and the amount of radioactivity incorporated into the cells measured with a liquid scintillation counter (Packard TRI-CARB ${ }^{\circ} 2200 \mathrm{CA}$ ). This was normalized with its protein content. The BCA-protein content of the dissolved cells were determined using the Pierce BCA-Protein Assay Kit and compared to a
BSA Standard-curve prepared in $0.2 \mathrm{M} \mathrm{NaOH}$. The glucose uptake data was expressed in cpm/mg of protein. $0.1 \mathrm{nM}$ insulin was used as a positive control. Non-specific glucose uptake was measured in the presence of $10 \mu \mathrm{M}$ of Cytochalasin B as an inhibitor of glucose transport.

\section{DPPH radical scavenging}

The antioxidant activity of MAB and fractions were evaluated on the basis of the radical scavenging effect of the stable DPPH free radical [18]. The DPPH scavenging activity was determined according to methods described by Brand WW [19] with slight modifications as follows in a 96 well plate. MAB and fractions were serially diluted in methanol to obtain a concentration range of $20-2000 \mu \mathrm{g} / \mathrm{mL}$. The reaction mixture was made up of $100 \mu \mathrm{L}$ of $0.5 \mathrm{mM} \mathrm{2,} \mathrm{2-diphenyl-1-}$ picrylhydrazyl radical (DPPH), and $100 \mu \mathrm{L}$ of each concentration of the test sample. For positive control or standard, ascorbic acid was used with methanol serving as the blank. Triplicate experiments were performed. The plates were covered with aluminum foil, shaken gently and kept in the dark for $20 \mathrm{~min}$ after which the absorbance was measured at $517 \mathrm{~nm}$. The mean percentage antioxidant activity for the triplicate experiment was plotted for the standard and samples and their effective concentration at $50 \%\left(\mathrm{EC}_{50}\right)$ values were determined by nonlinear regression analysis.

\section{Nitric oxide radical scavenging}

Nitric oxide (NO) is generated from sodium nitroprusside in aqueous solution at physiological $\mathrm{pH}$. It interacts with superoxides to produce peroxynitrite ions, which were measured using the Griess reaction reagent [20]. $3.0 \mathrm{~mL}$ of $10 \mathrm{mM}$ sodium nitroprusside in phosphate buffer was added to $2.0 \mathrm{~mL}$ of extract (MAB and fractions) and reference compound in different concentrations $(20-2000 \mu \mathrm{g} / \mathrm{ml})$. The resulting solutions were then incubated at $25^{\circ} \mathrm{C}$ for 60 minutes. A similar procedure was repeated with methanol as blank, which served as control. To $5.0 \mathrm{ml}$ of the incubated sample, $5.0 \mathrm{ml}$ of Griess reagent ( $1 \%$ sulphanilamide, $0.1 \%$ naphthyethylenediamine dihydrochloride in $2 \% \mathrm{H}_{3} \mathrm{PO}_{4}$ ) were added and absorbances of the chromophore formed were measured at $540 \mathrm{~nm}$. The standard compound employed was $\alpha$ tocopherol.

\section{Total antioxidant capacity}

Phosphomolybdenum method as described by Prieto $\mathrm{P}$ [21] used to determine the total antioxidant capacity of MAB where absorbance was measured at $695 \mathrm{~nm}$ against the blank. The antioxidant activity was expressed as the number of equivalents of ascorbic acid.

\section{Total phenol content}

Folin Ciocalteu's reagent method [22] was used for phenol content determination. MAB $(1 \mathrm{ml}$ of $0.0125-1 \mathrm{mg} / \mathrm{mL})$ in methanol was separately mixed with $1 \mathrm{ml}$ Folin Ciocalteu's reagent and $1 \mathrm{~mL}$ of aqueous $\mathrm{Na}_{2} \mathrm{CO}_{3}(2 \%)$. The mixture was incubated at $25^{\circ} \mathrm{C}$ for $2 \mathrm{~h}$, and then centrifuged at $10000 \mathrm{~g}$ for $10 \mathrm{~min}$. The absorbance of the supernatant was determined at $760 \mathrm{~nm}$. Methanol $(1 \mathrm{~mL})$ was also processed in the same way as the test drugs and used as blank. The standard curve was prepared by preparing tannic acid solutions $(0.02-0.1 \mathrm{mg} / \mathrm{mL})$ in methanol. Total phenol values were expressed in terms of tannic acid equivalents ( $\mathrm{mg} / \mathrm{g}$ of dry mass). 
Citation: Harley BK, Dickson RA, Fleischer TC (2017) Antioxidant, Glucose Uptake Stimulatory, $\alpha$-Glucosidase and $\alpha$-Amylase Inhibitory Effects of Myrianthus arboreus Stem Bark. Nat Prod Chem Res 5: 271. doi:10.4172/2329-6836.1000271

Page 4 of 7

\section{Reducing power assay}

Potassium ferricyanide method was used to determine the reducing power of MAB. Absorbance was measured at $700 \mathrm{~nm}$ and higher absorbance indicates stronger reducing power [23].

\section{Statistical analysis}

Results were presented as mean \pm S.D values. One way ANOVA and Dunnett's multiple comparisons test (Graphpad Prism version 6) was carried out to compare the data with the with the level of significance set at $P<0.05$ against the control. Where appropriate the significance difference between two means was analyzed using unpaired $t$ test.

\section{Results}

\section{Effects of $M$. arboreus stem bark extract and fractions on $\alpha$ - glucosidase and $\alpha$-amylase activities}

The enzyme inhibitory activities of the ethanol stem bark extract of $M$. arboreus in comparison with the known antidiabetic drug, acarbose on $\alpha$-glucosidase and $\alpha$-amylase are shown in Figures 1 and 2 respectively. The $\mathrm{IC}_{50}$ values obtained for acarbose and MAB in the $\alpha-$ glucosidase inhibition assay are $121.90 \pm 1.55 \mu \mathrm{g} / \mathrm{mL}$ and $11.11 \pm 0.52$ $\mu \mathrm{g} / \mathrm{mL}$ respectively. Whereas the $\mathrm{IC}_{50}$ values obtained for the $\alpha$ amylase inhibitory activity was $67.20 \pm 2.59 \mu \mathrm{g} / \mathrm{mL}$ and $13.56 \pm 1.13$ $\mu \mathrm{g} / \mathrm{mL}$ respectively. Table 1 shows the $\alpha$-glucosidase and $\alpha$-amylase inhibitory activities of the fractions of MAB. The fractions exhibited varying degrees of inhibition of both enzymes, with the highest activity being recorded with the ethyl acetate fraction (MAB3).

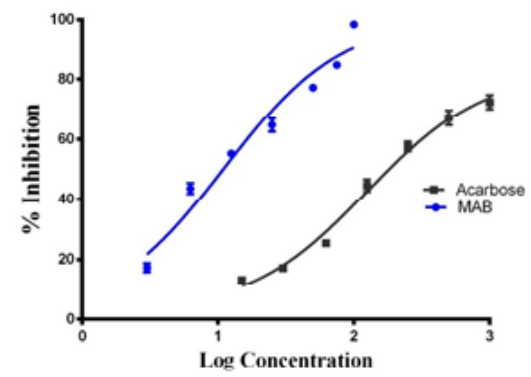

Figure 1: $\alpha$-Glucosidase inhibitory activity of $M$. arboreus stem bark and Acarbose. Data expressed as Mean \pm S.D $(n=3)$. MAB: Ethanol extract.

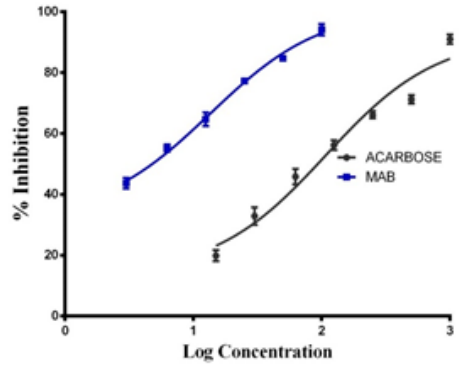

Figure 2: $\alpha$-Amylase Inhibitory activity of $M$. arboreus stem bark and Acarbose. Data expressed as Mean \pm S.D $(n=3)$. MAB: Ethanol extract.

\section{Glucose uptakea of $M$. arboreus stem bark extract and fractions}

The crude ethanol extract and fractions of $M$. arboreus were tested for their effect on glucose uptake in differentiated $\mathrm{C} 2 \mathrm{C} 12$ myotubes and 3T3-L1 adipocytes using insulin-like Growth factor 1(IGF-1) and insulin as positive controls respectively. Glucose uptake determination in $\mathrm{C} 2 \mathrm{C} 12$ myotubes revealed that the crude extract and fractions exhibited varying glucose uptake stimulatory effects with significant potentiation (ranging between $120 \%$ and 160\%) of glucose uptake occurring with the chloroform fraction (MAB2) and the ethyl acetate fraction (MAB3) fraction as compared to the control (medium) (100\%, $P<0.05)$ (Figure 3$)$. The crude extract $(\mathrm{MAB})$ and the aqueous fraction (MAB5) at $30 \mu \mathrm{g} / \mathrm{ml}$ also demonstrated significant glucose uptake stimulatory effect of $134.24 \% \pm 9.41$ and $128.51 \% \pm 11.02$ compared to the control respectively. All the fractions except the petroleum ether fraction $(\mathrm{MAB} 1)$ significantly $(P<0.05)$ enhanced the uptake of glucose in 3T3-L1 cells $(120 \%-180 \%)$ with the highest uptake recorded in cells treated with the ethyl acetate fraction (Figure 4).

\section{Antioxidant effects of $M$. arboreus stem bark extract and fractions}

The crude ethanol extract of $M$. arboreus, MAB, exhibited a concentration-dependent DPPH radical scavenging effect with an $\mathrm{IC}_{50}$ of $98.64 \pm 1.99 \mu \mathrm{g} / \mathrm{ml}$ (Figure 5). The $\mathrm{IC}_{50}$ value of vitamin $\mathrm{C}$ was 23.78 $\pm 1.38 \mu \mathrm{g} / \mathrm{ml}$. It also exhibited a concentration-dependent effect against NO radical (Figure 6) with an $\mathrm{IC}_{50}$ of $167.4 \pm 2.22 \mu \mathrm{g} / \mathrm{ml}$. $\alpha$ Tocopherol, with an $\mathrm{IC}_{50}$ of $45.55 \pm 1.66 \mu \mathrm{g} / \mathrm{ml}$ was more active than MAB. The fractions of MAB showed significant scavenging effect on the DPPH and NO radicals. The ethyl acetate (MAB3) fraction proved to be the most active against both radicals (Table 2).

\section{Total antioxidant and total phenol content of $M$. arboreus stem bark}

The content of total phenols measured by Folin-Ciocalteau's reagent in terms of tannic acid equivalents $(\mathrm{mg} / \mathrm{g}$ ) (Standard curve equation: $\left.\mathrm{y}=10.86 \mathrm{x}+0.01641, \mathrm{r}^{2}=0.994\right)$ was $114.70 \pm 10.48$. MAB showed good antioxidant capacity which had a strong correlation with the total phenol content of the plant. The total antioxidant capacity of the extract in terms of ascorbic acid equivalent $(\mathrm{mg} / \mathrm{g}$ ) (the standard curve equation: $\mathrm{y}=6.908 \mathrm{x}+0.046, \mathrm{r}^{2}=0.9832$ ) was $98.34 \pm 14.50$. 
Citation: Harley BK, Dickson RA, Fleischer TC (2017) Antioxidant, Glucose Uptake Stimulatory, $\alpha$-Glucosidase and $\alpha$-Amylase Inhibitory Effects of Myrianthus arboreus Stem Bark. Nat Prod Chem Res 5: 271. doi:10.4172/2329-6836.1000271

Page 5 of 7

\begin{tabular}{|c|c|c|}
\hline & \multicolumn{2}{|c|}{ IC $_{50}(\mu \mathrm{g} / \mathrm{mL})$} \\
\hline Extract/Fraction & $\alpha$-Glucosidase & \multicolumn{1}{|c|}{$13.56 \pm 1.13$} \\
\hline MAB & $11.11 \pm 0.52$ & $321.95 \pm 6.28$ \\
\hline MAB1 & $329.35 \pm 10.25$ & $30.34 \pm 2.15$ \\
\hline MAB2 & $47.03 \pm 2.13$ & $3.75 \pm 1.66$ \\
\hline MAB3 & $6.64 \pm 0.36$ & $74.51 \pm 0.32$ \\
\hline MAB4 & $82.10 \pm 2.33$ & $96.32 \pm 0.55$ \\
\hline MAB5 & $210.23 \pm 6.15$ & $67.20 \pm 2.59$ \\
\hline Acarbose & $121.90 \pm 1.55$ & \\
\hline
\end{tabular}

Table 1: Effect of M. arboreus stem bark extract and fractions on a-glucosidase and a-amylase. MAB: Ethanol extract, MAB1: Petroleum Ether fraction, MAB2: Chloroform fraction; MAB3: Ethyl acetate fraction, MAB4: n-Butanol fraction, MAB5: Aqueous Residue.

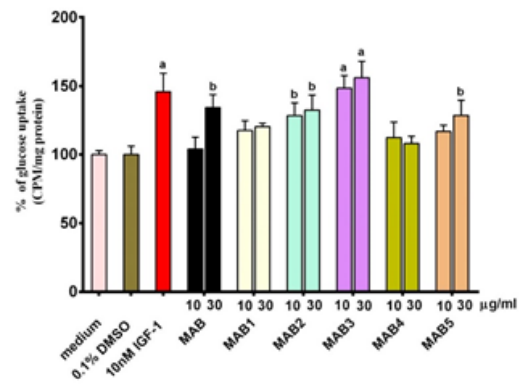

Figure 3: Glucose Uptake Activity of $M$. arboreus fractions obtained from Liquid-Liquid Extraction in $\mathrm{C} 2 \mathrm{C} 12$ myotubes. ${ }^{\mathrm{a}} P<0.001$, ${ }^{b} P<0.01$ compared to control. MAB: Ethanol extract; MAB1: Petroleum Ether fraction, MAB2: Chloroform fraction; MAB3: Ethyl acetate fraction; MAB4: n-Butanol fraction, MAB5: Aqueous Residue.

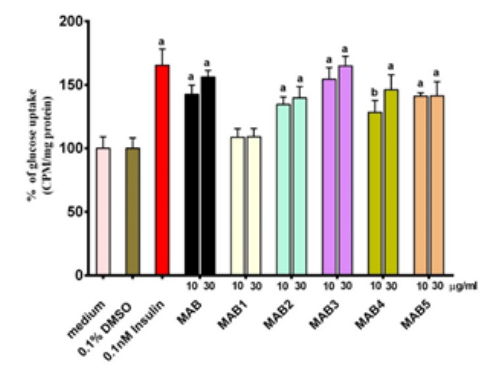

Figure 4: Glucose Uptake Activity of $M$. arboreus fractions obtained from Liquid-Liquid Extraction in 3T3-L1 adipocytes. ${ }^{a} P<0.001$, ${ }^{\mathrm{b}} P<0.01$ compared to control. MAB: Ethanol extract; MAB1: Petroleum Ether fraction, MAB2: Chloroform fraction; MAB3: Ethyl acetate fraction; MAB4: n-Butanol fraction, MAB5: Aqueous Residue.

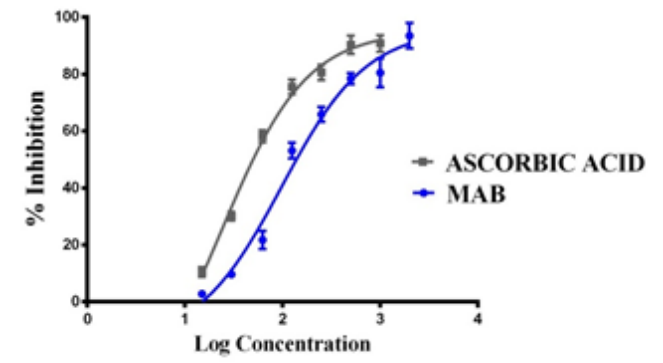

Figure 5: DPPH scavenging effect of $M$. arboreus stem bark and Ascorbic acid. Data are expressed as mean \pm S.D. $(n=3)$. MAB: Ethanol extract.

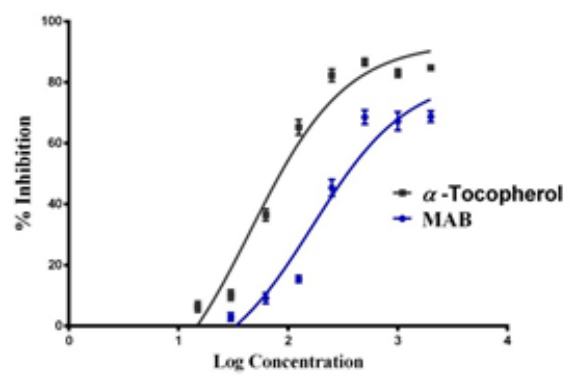

Figure 6: Nitric oxide scavenging effect of $M$. arboreus stem bark and $\alpha$-tocopherol. Data are expressed as mean \pm S.D. $(\mathrm{n}=3)$. MAB: Ethanol extract.

\section{Reducing power of $M$. arboreus stem bark}

The ethanol stem bark extract of $M$. arboreus exhibited good reducing power potential which with was concentration dependent, although the reductive ability of ascorbic acid was higher (Figure 7). 


\begin{tabular}{|c|c|c|}
\hline & \multicolumn{2}{|c|}{ IC $_{50}(\boldsymbol{\mu g} / \mathrm{mL})$} \\
\hline Extract/Fraction & DPPH Radical & NO Radical \\
\hline MAB & $98.64 \pm 1.99$ & $167.4 \pm 2.22$ \\
\hline MAB1 & $315.26 \pm 2.14$ & $235.32 \pm 1.89$ \\
\hline MAB2 & $79.35 \pm 2.25$ & $86.43 \pm 0.45$ \\
\hline MAB3 & $32.19 \pm 1.93$ & $68.75 \pm 0.78$ \\
\hline MAB4 & $115.41 \pm 2.62$ & $134.56 \pm 2.66$ \\
\hline MAB5 & $227.04 \pm 1.70$ & $240.43 \pm 3.01$ \\
\hline Vitamin C & $23.78 \pm 1.38$ & - \\
\hline Vitamin E & - & $45.55 \pm 1.66$ \\
\hline
\end{tabular}

Table 2: Effect of $M$. arboreus stem bark extract and fractions DPPH and Nitric Oxide radicals. MAB: Ethanol extract, MAB1: Petroleum Ether fraction, MAB2: Chloroform fraction; MAB3: Ethyl acetate fraction, MAB4: n-Butanol fraction, MAB5: Aqueous Residue.

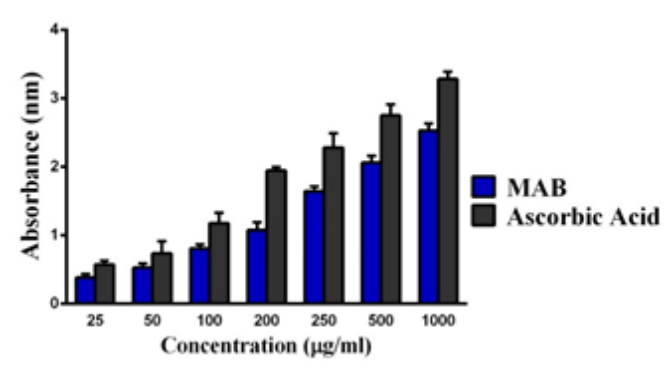

Figure 7: Reducing power of $M$. arboreus stem bark and Ascorbic acid based on measurement of $\mathrm{Fe}^{3+}-\mathrm{Fe}^{2+}$ transformation. Data are expressed as mean \pm S.D. $(n=3)$. MAB: Ethanol extract.

\section{Discussion}

The crude ethanol extract of $M$. arboreus has been shown to possess antidiabetic activity at doses of 100, 200 and $400 \mathrm{mg} / \mathrm{kg}$ between in STZ-induced diabetic rat model [14]. However, the exact mechanism for its blood glucose lowering effect was not clear. The current study therefore was designed to explore the antidiabetic potential of the ethanol stem bark extract of $M$. arboreus and evaluate various fractions of the crude extract for glucose uptake stimulatory action in skeletal muscles and the adipose tissues, inhibition of carbohydrate metabolizing enzymes, $\alpha$-glucosidase and $\alpha$-amylase, along with its antioxidant potential. The stem bark extract of $M$. arboreus showed remarkable levels of enzyme inhibition potency with about 11-fold and 5 -fold better activity than the antidiabetic drug, acarbose in the anti- $\alpha$ glucosidase and anti- $\alpha$-amylase assays, respectively. The ethyl acetate fraction was found to possess the most potent enzyme inhibitory activity amongst the fractions with about 20 -fold and 18 -fold better activity than acarbose in the anti- $\alpha$-glucosidase and anti- $\alpha$-amylase assays, respectively. Results of the current study indicate that the antidiabetic activity of $M$. arboreus may be mediated by its strong inhibitory effect on the amylase and glucosidase activity. The crude extract and fractions remarkably stimulated glucose uptake in fully differentiated $\mathrm{C} 2 \mathrm{C} 12$ myotubes and 3T3-L1 adipocytes. An important finding of the study is that the extract of $M$. arboreus possesses considerable insulin-like properties as evidenced by enhancement of glucose uptake in the cell-based assays. Further work is required to elucidate the mechanism by which this effect is mediated. However, glucose uptake in $\mathrm{C} 2 \mathrm{C} 12$ skeletal cells was much lower than observed in the adipocytes indicating a higher affinity for glucose uptake of the extract and fractions in adipose tissues than skeletal muscles, although the skeletal muscle is the major site for primary glucose disposal and utilization [24]. The ethyl acetate fraction demonstrated the highest enhancement of glucose uptake in both C2C12 myotubes and 3T3-L1 adipocytes. These findings suggest that the hypoglycemic effect of $M$. arboreus could be due to its ability to modulate the uptake of glucose from the blood stream into the skeletal muscles and adipose tissues as well as its inhibitory effect on digestive enzymes. It is worth noting that this is the first-time report of the glucose uptake stimulatory action of $M$. arboreus. The molecular mechanism by which the extract exerts this activity however should be investigated

One of the well-recognized fundamental mechanism in the pathogenesis of chronic diabetes complications is oxidative stress, resulting from increased production of ROS [25], thus attenuating hyperglycemia-triggered oxidative stress may provide alternative approaches in preventing the development of diabetes and diabetic complications. Indeed, it has been reported that ROS can induce insulin resistance [10,26], impair insulin synthesis [27], and impair $\beta$ cell insulin secretion [9]. In the present study, we reported for the first time, the antioxidant activities of $M$. arboreus stem bark extract and fractions against the DPPH and NO radicals. In the DPPH test, the stem bark extract was able to reduce the stable radical DPPH to the yellow colored diphenyl picrylhydrazine. The method was based on the reduction of alcoholic DPPH solution in the presence of a hydrogendonating antioxidant to the non-radical form DPPH-H [19]. Nitric oxide (NO), a free radial, when produced in vivo, plays important biological functions in the body. Endothelium-derived NO modulates blood vessels, inhibits blood clotting by preventing platelet aggregation, regulates apoptosis and maintains endothelial cell barrier function [28]. NO acts as a messenger for the neurons in the brain and other parts of the body [29], whereas NO produced as part of the immune system enables white blood cells to kill tumour cells and bacteria [30]. NO and superoxide $\left(\mathrm{O}_{2}\right)$ react to form a highly reactive peroxynitrite which has deleterious effects on cells and cellular function. The NO radical inhibition study showed that MAB was a potent scavenger of nitric oxide. MAB inhibited nitrite formation by competing with oxygen to react with $\mathrm{NO}$ directly and also to inhibit its synthesis. Given the potent antioxidant activities of the crude extract, it was worthwhile to analyze the scavenging effect of its fractions. Once again, the ethyl acetate fraction demonstrated the highest scavenging effect on the DPPH and NO radicals, whiles the other fractions showed moderate to low scavenging activity.

The total phenolic content of the crude ethanol extract that could contribute to the observed antioxidant activity was also investigated. The Folin-Ciocalteu reagent assay indicated an incredibly high polyphenolic value in the extract. It has also been noted that the antioxidant effect of many compounds could be attributed in part to their reducing power [31]. Hence, the reductive capacity of the $M$. arboreus was also assessed by measuring the $\mathrm{Fe}^{3+}-\mathrm{Fe}^{2+}$ transformation in the presence the crude extract. The demonstrated concentration-dependent reducing power effect, which was comparable with ascorbic acid, was a further demonstration of the potent antioxidant potential of $M$. arboreus stem bark extract. 


\section{Conclusion}

In conclusion, the ethanol stem bark extract of $M$. arboreus demonstrated remarkable ability to enhance the uptake of glucose into the muscle cells and adipose tissues and also showed potent activities against $\alpha$-glucosidase and $\alpha$-amylase. The extract also exhibited good antioxidant activities. Given that the most potent enzyme inhibition, glucose uptake stimulatory and highest antioxidant effects were recorded by the ethyl acetate fraction, further studies on the identification of the active principles in it are warranted.

\section{Conflict of Interest}

The authors wish to declare no conflict of interest.

\section{Acknowledgement}

This work was supported with funds from the Kwame Nkrumah University of Science Technology (KNUST) Research Fund (KReF). Novartis is also gratefully acknowledged for sponsoring Benjamin Kingsley Harley to participate in the Novartis Diversity and Inclusion Next Generation Scientist Programme in their Musculoskeletal Disease Area Basel, Switzerland.

\section{References}

1. Alberti KGMM, Zimmet PF (1998) Definition, diagnosis and classification of diabetes mellitus and its complications. Part 1: diagnosis and classification of diabetes mellitus. Provisional report of a WHO consultation. Diabet Med 15: 539-553.

2. Guariguata L, Whiting D, Hambleton I, Beagley J, Linnenkamp U, et al. (2014) Global estimates of diabetes prevalence for 2013 and projections for 2035. Diabetes Res Clin Pract 103: 137-149.

3. Whiting DR, Guariguata L, Weil C, Shaw J (2011) IDF diabetes atlas: global estimates of the prevalence of diabetes for 2011 and 2030. Diabetes Res Clin Pract 94: 311-321.

4. Tangvarasittichai S (2015) Oxidative stress, insulin resistance, dyslipidemia and type 2 diabetes mellitus. World J Diabetes 6: 456-480.

5. Sottero B, Gargiulo S, Russo I, Barale C, Poli G, et al. (2015) Postprandial dysmetabolism and oxidative stress in type 2 diabetes: pathogenetic mechanisms and therapeutic strategies. Med Res Rev 35: 968-1031.

6. Chai TT, Khoo CS, Tee CS, Wong FC (2016) Alpha-glucosidase inhibitory and antioxidant potential of antidiabetic herb Alternanthera sessilis: Comparative analyses of leaf and callus solvent fractions. Pharmacogn Mag 12: 253-258.

7. Yan LJ (2014) Pathogenesis of chronic hyperglycemia: from reductive stress to oxidative stress. J Diabetes Res 2014.

8. Rahimi R, Nikfar S, Larijani B, Abdollahi M (2005) A review on the role of antioxidants in the management of diabetes and its complications. Biomed Pharmacother 59: 365-373.

9. Fernández-Millán E, Ramos S, Alvarez C, Bravo L, Goya L, et al. (2014) Microbial phenolic metabolites improve glucose-stimulated insulin secretion and protect pancreatic beta cells against tert-butyl hydroperoxide-induced toxicity via ERKs and PKC pathways. Food Chem Toxicol 66: 245-253.

10. D'apolito M, Du X, Zong H, Catucci A, Maiuri L, et al. (2014) Ureainduced ROS generation causes insulin resistance in mice with chronic renal failure. J Clin Invest 124: 4668-4668.

11. Abbiw DK (1990) Useful plants of Ghana: West African uses of wild and cultivated plants. Intermediate Technology Publications and The Royal Botanic Gardens.
12. Okafor J (1980) Edible indigenous woody plants in the rural economy of the Nigerian forest zone. For Ecol Manage 3: 45-55.

13. Burkill H (1985) The useful plants of West Tropical Africa. Families AD Royal Botanic Gardens Kew. Library MARC record.

14. Dickson RA, Harley BK, Berkoh D, Ngala RA, Titiloye NA, et al. (2016) Antidiabetic and haematological effect of Myrianthus arboreus P. Beauv. Stem bark extract in streptozotocin - induced diabetic rat. Int J Pharm Sci Res 7: 4812 .

15. Worthington V (1993) Worthington Biochemical Corp. Freehold NJ, pp: 293-294.

16. Haghani K, Pashaei S, Vakili S, Taheripak G, Bakhtiyari S (2015) TNF-a knockdown alleviates palmitate-induced insulin resistance in $\mathrm{C} 2 \mathrm{C} 12$ skeletal muscle cells. Biochem Biophys Res Commun 460: 977-982.

17. Hu B, Amin R, Kumar S, Kunaparaju N, Graham S (2014) Bioassayguided isolation of the antidiabetic active principle from Salvia miltiorrhiza and its stimulatory effects on glucose uptake using 3T3-L1 adipocytes. Med Chem 4: 592-597.

18. Blois MS (1958) Antioxidant determinations by the use of a stable free radical. Nature 181: 1199-1200.

19. Brand WW, Cuvelier ME, Berset C (1995) Use of a free radical method to evaluate antioxidant activity. Lebenson Wiss Technol 28: 25-30.

20. Green LC, Wagner DA, Glogowski J, Skipper PL, Wishnok JS, et al. (1982) Analysis of nitrate, nitrite, and $[15 \mathrm{~N}]$ nitrate in biological fluids. Anal Biochem 126: 131-138.

21. Prieto P, Pineda M, Aguilar M (1999) Spectrophotometric quantitation of antioxidant capacity through the formation of a phosphomolybdenum complex: specific application to the determination of vitamin E. Anal Biochem 269: 337-341.

22. Mcdonald S, Prenzler PD, Antolovich M, Robards K (2001) Phenolic content and antioxidant activity of olive extracts. Food Chem 73: 73-84.

23. Athukorala Y, Kim KN, Jeon YJ (2006) Antiproliferative and antioxidant properties of an enzymatic hydrolysate from brown alga, Ecklonia cava. Food Chem Toxicol 44: 1065-1074.

24. Anandharajan R, Jaiganesh S, Shankernarayanan N, Viswakarma R, Balakrishnan A (2006) In vitro glucose uptake activity of Aegles marmelos and Syzygium cumini by activation of Glut-4, PI3 kinase and PPAR $\gamma$ in L6 myotubes. Phytomedicine 13: 434-441.

25. Nickel A, Kohlhaas M, Maack C (2014) Mitochondrial reactive oxygen species production and elimination. J Mol Cell Cardiol 73: 26-33.

26. Watanabe T, Saotome M, Nobuhara M, Sakamoto A, Urushida T, et al. (2014) Roles of mitochondrial fragmentation and reactive oxygen species in mitochondrial dysfunction and myocardial insulin resistance. Exp Cell Res 323: 314-325.

27. Fu Z, Gilbert E, Liu D (2013) Regulation of insulin synthesis and secretion and pancreatic Beta-cell dysfunction in diabetes. Curr Diabetes Rev 9: 25-53.

28. Snyder SH, Bredt DS (1992) Biological roles of nitric oxide. Sci Am 266: 68-71.

29. Rosselli M, Keller R, Dubey RK (1998) Role of nitric oxide in the biology, physiology and pathophysiology of reproduction. Hum Reprod Update 4: 3-24.

30. Nagy G, Koncz A, Telarico T, Fernandez D, Érsek B, et al. (2010) Central role of nitric oxide in the pathogenesis of rheumatoid arthritis and sysemic lupus erythematosus. Arthritis Res Ther 12: 210.

31. Benzie IF, Strain J (1996) The ferric reducing ability of plasma (FRAP) as a measure of "antioxidant power": the FRAP assay. Anal Biochem 239: 70-76. 